\title{
MODEL ACTIVITY BASED COSTING PADA SEKOLAH MENENGAH KEJURUAN
}

\author{
Sri Sumardiningsih, Sugiharsono, Mimin Nur Aisyah \& Aula Ahmad Hafidh Saiful Fikri \\ Universitas Negeri Yogyakarta, Indonesia \\ sumardiningsih@uny.ac.id,sugiharsono@uny.ac.id,mimin_nuraisyah@uny.ac.id,aula_hsf@uny.ac.id
}

\begin{abstract}
Abstrak: Penelitian ini bertujuan mengetahui alokasi dana pendidikan ke seluruh aktivitas yang ada di sekolah, unit cost pelayanan pendidikan tiap siswa di setiap tingkat dan paket keahlian, dan perbandingan unit cost pelayanan pendidikan di setiap tingkat dan paket keahlian dihitung dengan $\mathrm{ABC}$ dan metode Traditional Costing. Objek penelitian yakni unit cost pelayanan pendidikan di SMK Negeri Yogyakarta 2016/2017. Pengumpulan data melalui wawancara dan dokumentasi, FGD. Menggunakan analisis data deskriptif. Hasil menunjukkan alokasi dana terbesar untuk biaya aktivitas belajar mengajar yaitu 55,77\%, paling rendah adalah biaya kegiatan manajemen sekolah $6,20 \%$, dan aktivitas lainnya sekitar 9\%. Unit cost per siswa dihitung dengan ABC dilihat antar Paket Keahlian berbedabeda, berkisar dari Rp 1.168.513 sampai Rp 1.424.116. Unit cost dengan Traditional Costing dibanding dengan $\mathrm{ABC}$ ada yang termasuk kategori undercosted dan overcosted. Biaya yang termasuk kategori overcosted adalah seluruh paket keahlian di kelas X dan kategori undercosted adalah pada seluruh paket keahlian di kelas XI dan XII.
\end{abstract}

Kata kunci: alokasi dana pendidikan, Activity Based Costing, Traditional Costing

\section{ACTIVITY BASED COSTING MODEL IN VOCATIONAL HIGH SCHOOL}

\begin{abstract}
The cost of education services for each student in each level and the package of expertise, and the cost of education services at each level and skills packages are calculated by $A B C$ and Traditional Costing methods. The object of this study is the unit of cost of education services in Yogyakarta 2016/2017 State Vocational School. Data collection through interview and documentation techniques, FGD. Data analysis using descriptive data analysis. The results of the funding for teaching and learning activities are $55.77 \%$, $6.20 \%$ of the lowest cost of school management activities, and other activities around $9 \%$. Unit cost per student is calculated with seen $\mathrm{ABC}$ between different skill packages, ranging from $\mathrm{Rp} 1,168,513$ to $\mathrm{Rp} 1,424,116$. Unit costs with Traditional Costing compared to ABC are categorized as undercosted and overcosted. Costs included in the overcosted category are all skill packages in X and undercosted categories in all skills packages in class XI and XII.
\end{abstract}

Keywords: The cost of education services, Activity Based Costing, Traditional Costing

\section{PENDAHULUAN}

Pendidikan merupakan salah satu pilar penting dalam meningkatkan kualitas sumber daya manusia. Undang-Undang Nomor 20 Tahun 2003 tentang Sistem Pendidikan Nasional, pasal 11 ayat (1) dan (2) menegaskan, pemerintah dan pemerintah daerah wajib memberikan layanan dan kemudahan, serta menjamin terselenggaranya pendidikan bermutu bagi setiap warga negara tanpa diskriminasi; dan wajib menjamin tersedianya dana bagi penyediaan pendidikan untuk setiap warganegara yang berusia 7-15 tahun.

Sejak tahun 2013 pemerintah melanjutkan program wajib belajar ke jenjang pendidikan menengah, sehingga menjadi program wajib belajar dua belas tahun (Kementrian Pendidikan dan Kebudayaan Direktorat Jenderal Pendidikan Menengah, 2003: 1). Wajib Belajar 12 tahun memungkinkan seluruh penduduk usia pendidikan menengah akan memiliki akses untuk mendapatkan pendidikan menengah (SMA, SMK, dan yang sederajat). 
Standar Pembiayaan dalam Permen No 9 Tahun 2009 sampai sekarang ini belum pernah disesuaikan, maka kajian ini sangat penting dalam rangka mempersiapkan pendanan program Wajar Dikmen 12 tahun. Apalagi dengan diberlakukannya Kurikulum 2013 kegiatan pendidikannya juga berubah, sehingga standar biaya sangat perlu dirumuskan kembali. Kajian mengenai Standar Pembiayaan perlu dilakukan dalam rangka mempersiapkan pendanan program Wajib Belajar Pendidikan Menengah 12 tahun. Oeh karena itu, pemerintah perlu segera merencanakan kebutuhan biaya penyelenggaraan pendidikan di tingkat SMA/SMK/MA dan yang sederajat dengan melakukan analisis biaya.

Menurut Matin (2014: 19-22), analisis biaya pendidikan berguna untuk 1) memperkirakan sumber pembiayaan yang disediakan untuk bidang pendidikan, 2) memantau dan memperbaiki penggunaan sumber daya secara efektif dan efisien, 3) menilai sumber yang diperlukan untuk melaksanakan keputusan dalam rangka pembangunan pendidikan, dan 4) menentukan pemilihan program atau proyek.

Saat ini lebih banyak sekolah yang menggunakan metode Tradisional dalam perhitungan biaya, namun perhitungan tersebut belum memiliki informasi mengenai jumlah biaya yang dikonsumi oleh masing-masing siswa pada tingkat dan paket keahlian yang berbeda. Padahal, informasi manajemen biaya dapat berguna untuk manajemen strategis, perencanaan dan pengambilan keputusan, pengendalian manajemen dan operasi, serta penyusunan laporan keuangan (Blocher, Stout, \& Cokins (2011: 7). Selain itu, informasi mengenai biaya dapat membantu manajemen dalam membuat dan melaksanakan rencana dan anggaran untuk operasi, menetapkan metode perhitungan biaya yang memungkinkan pengendalian aktivitas, pengurangan biaya, dan perbaikan kualitas, mengendalikan kuantitas fisik dari persediaan dan menentukan biaya dari setiap produk dan jasa yang dihasilkan, menentukan biaya dan laba untuk satu tahun periode akuntansi atau periode lain yang lebih pendek, dan memilih antara dua atau lebih alternatif jangka pendek atau jangka panjang Carter \& Usry (2006: 11). Manfaat-manfaat tersebut menunjukkan perlunya informasi manajemen biaya yang baik dan lengkap agar efesiensi biaya dapat dilaksanakan.

SMKN 2 Yogyakarta ditetapkan sebagai lokasi penelitian karena memiliki variasi produk pendidikan yang relatif banyak. Ada 9 (sembilan) Paket Keahlian di SMKN 2 Yogyakarta, yaitu Teknik Gambar Bangunan, Teknik Konstruksi Batu \& Beton, Teknik Geomatika, Teknik Audio Video, Teknik Komputer \& Jaringan, Multimedia, Teknik Instalasi Tenaga Listrik, Teknik Pemesinan, dan Teknik Kendaraan Ringan. Jadi dari sembilan Paket Keahlian yang masing-masing terdiri tiga tingkat/kelas, maka keseluruhan terdapat 27 produk jasa pendidikan. Setiap Paket Keahlian di tingkat yang berbeda memiliki aktivitas yang berbeda-beda, sehingga unit cost untuk setiap siswa berbeda-beda. Saat ini, sekolah belum memiliki informasi mengenai biaya per unit di setiap Paket Keahlian dan Tingkat. Oleh karena itu, sekolah perlu menerapkan Model Activity Based Costing (untuk selanjutnya akan disingkat dengan $\mathrm{ABC}$ ) agar mendapatkan informasi mengenai unit cost pada setiap Paket Keahlian dan Kelas lebih akurat. Variasi pelayanan serta keanekaragaman dan tingkat perbedaan pendukung pelayanan yang digunakan untuk setiap produk merupakan faktor yang perlu dipertimbangkan sebelum menerapkan ABC (Raiborn \& Kinny, 2011: 170). Pandangan Raiborn dan Kinny tersebut sesuai dengan kondisi SMKN 2 Yogyakarta yang memiliki produk pelayanan yang cukup bervariasi, yaitu sebanyak 27 produk jasa, sehingga penerapan ABC cocok untuk dilakukan agar dapat menyediakan informasi biaya yang lebih lengkap dan akurat.

ABC membebankan biaya berdasarkan besarnya konsumsi sumber daya dan pemakaian aktivitas setiap obyek biaya (Bustami \& Nulela, 2009). ABC dapat digunakan oleh sekolah karena $\mathrm{ABC}$ merupakan pendekatan yang kuat bagi lembaga pendidikan karena menyediakan informasi biaya yang lebih baik dan akurat (Abu-Tapanjeh-2008). Keuntungan yang dimiliki oleh ABC yaitu 
(Mulyadi, 2002: 93): 1) kemampuan ABC menyediakan informasi yang berlimpah tentang aktivitas yang digunakan untuk menghasilkan produk dan jasa bagi customer, 2) ABC menyediakan fasilitas untuk menyusun dengan cepat anggaran berbasis aktivitas, 3) menyediakan informasi biaya untuk memantau implementasi rencana pengurangan biaya, dan 4) ABC menyediakan secara akurat dan multidimensi biaya produk dan jasa yang dihasilkan. Oleh karena itu, perhiungan Biaya Satuan menggunakan model ABC perlu dilakukan agar sekolah memiliki informasi biaya satuan untuk setiap Paket Keahlian dan Tingkat.

Penerapan model ABC di perguruan tinggi dapat menilai permasalahan anggaran dan programatik dari laporan keuangan dengan lebih akurat dan lebih baik serta merupakan bagian dari Activity Based Management yang lebih luas (Abu-Tapanjeh: 2008). Temuan dari penerapan ABC di Universitas Kebangsaan Malaysia (Maelah, Amir, Ahmad, Auzair: 2011) menjadi perhatian berbagai pihak karena dapat memberikan informasi yang lebih lengkap. Informasi dari penerapan $\mathrm{ABC}$ tidak hanya berguna bagi manajemen saja, tetapi juga dapat digunakan oleh Kementrian Pendidikan, perguruan tinggi lain, sponsor, siswa, orang tua siswa, dan masyarakat umum (Maelah, Amir, Ahmad, Auzair: 2011). Oleh karena itu, perlu dilakukan penerapan Model ABC di SMKN 2 Yogyakarta agar dapat diperoleh informasi yang lebih akurat dan lengkap sehingga dapat digunakan sebagai dasar pengambilan keputusan oleh berbagai pihak serta dijadikan sebagai salah satu dasar pelaksanaan efisiensi biaya.

\section{METODE}

Penelitian ini merupakan penelitian deskriptif. Subyek penelitian merupakan sumber data yang dimintai informasinya sesuai dengan masalah penelitian. Subyek penelitian dalam penelitian ini ditentukan dengan pertimbangan orang yang dipandang dapat memberikan data dan keterangan secara tepat dan jelas mengenai obyek penelitian. Subyek penelitian meliputi bendahara sekolah dan kepala bagian tata usaha. Adapun obyek dalam penelitian ini yakni unit cost pelayanan pendidikan siswa di SMKN di Daerah Istimewa Yogyakarta tahun 2017/2018. Data dikumpulkan dengan metode wawancara dan dokumentasi, serta FGD (focus group discussion). Wawancara dilakukan dalam rangka cross-check data agar memperoleh gambaran kondisi sesungguhnya. serta untuk mengetahui aktivitas yang dilaksanakan pada proses manajerial, proses utama dan proses pendukung agar dapat melakukan mapping terhadap cost component yang relevan bagi perhitungan unit cost. Dokumentasi dilakukan untuk mengumpulkan dokumen sekolah seperti data siswa, data pendidik dan tenaga kependidikan, data sarana prasarana, RKAS, Realisasi RKAS, Dokumen Pelaksanaan Perubahan Anggaran (DPPA), dan Laporan Kas Komite.

Analisis data dalam penelitian ini dilengkapi dengan perangkat berupa template excel berisi format/tabel perhitungan biaya satuan dengan model ABC. Template tersebut berisikan tabel yang terdiri dari tabel data jumlah siswa, data tenaga pendidik dan Tenaga Kependidikan, Rekapitulasi Aktivitas Pengembangan sekolah, rekapitulasi aktivitas administrasi sekolah, rekapitulasi aktivitas manajemen sekolah, rekapitulasi pengelolaan sarana prasarana, pembebanan aktivitas pengembangan sekolah, pembebanan aktivitas administrasi sekolah, pembebanan aktivitas manajemen sekolah, pembebanan pengelolaan sarana prasarana, penentuan dan perhitungan cost driver, pembebanan tarif aktivitas ke obyek biaya, dan rekapitulasi biaya satuan. Template tersebut kemudian dipakai untuk menghitung biaya satuan di SMKN di DIY.

Tahapan implementasi ABC yaitu 1) Identifikasi Aktivitas dan Atribut Aktivitas; hasil dari Identifikasi Aktivitas dan Atribut Aktivitas adalah kamus aktivitas yang menjelaskan mengenai kegiatan aktivitas yang telah diidentifikasi 2) Pembebanan Biaya ke Aktivitas, 3) Pengumpulan biaya ke cost pool, dan 4) Pembebanan biaya ke obyek biaya. (Hansen \& Mowen, 2009: 176-185). 
Mengacu Hansen \& Mowen, tahap implementasi ABC dalam penelitian ini disajikan dalam Gambar 1.

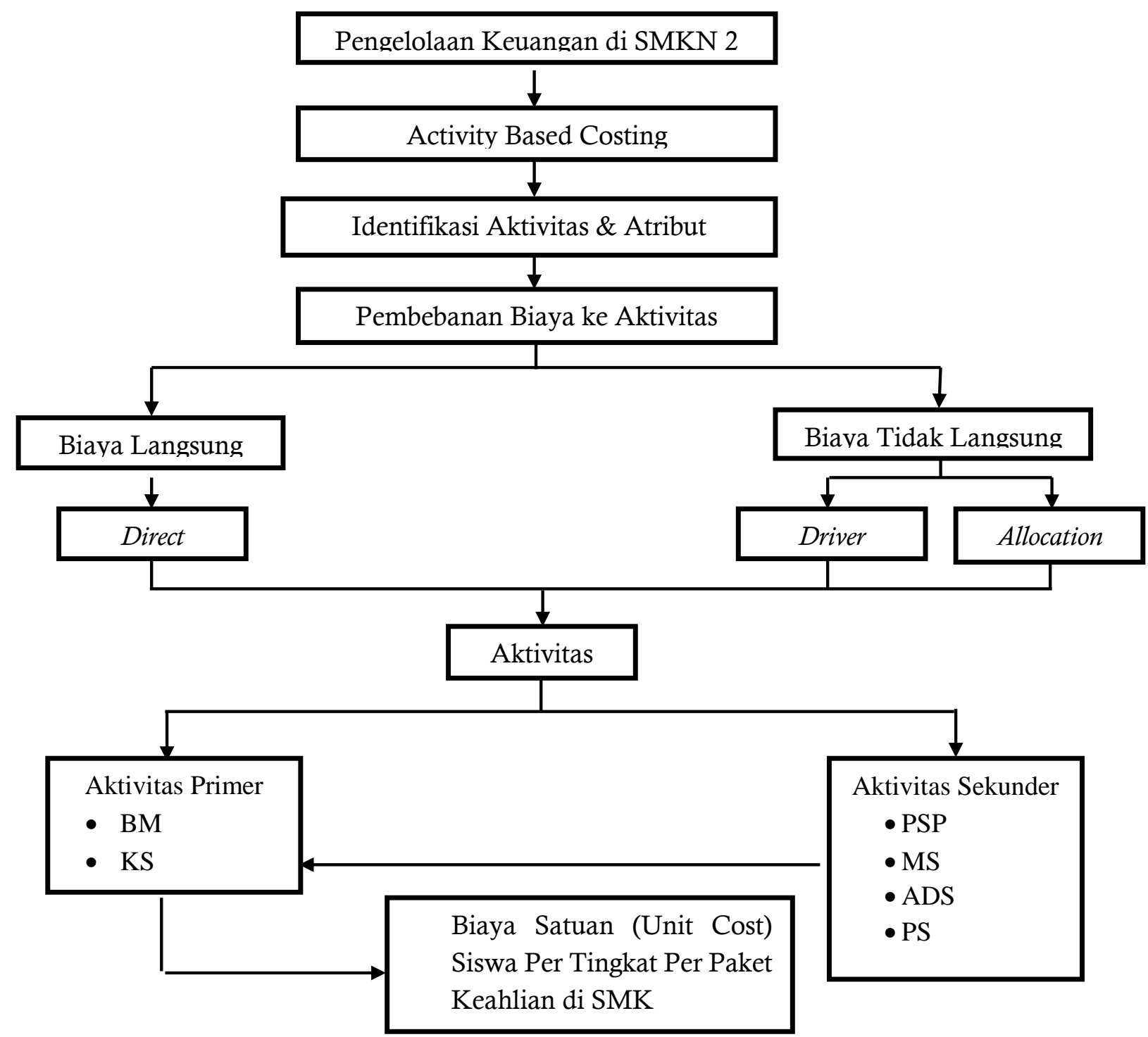

Gambar 1. Tahap Implementasi Model ABC

Keterangan:

$\mathrm{BM}$ = belajar mengajar (belajar mengajar antar Paket Keahlian, belajar mengajar antar rombel, belajar mengajar khusus kelas XII, belajar mengajar berdasarkan jam pelajaran)

KS = kesiswaan (kesiswaan khusus kelas X, kesiswaan untuk seluruh siswa)

PSP = pengelolaan sarana prasarana (pemeliharaan dan pengadaan sarana sekolah, pengadaan alat praktik dan alat kantor, pengadaan prasarana sekolah)

MS = manajemen sekolah (rapat komite, manajemen mutu, rapat dinas, pemberdayaan komite)

ADS = administrasi sekolah (dokumentasi publikasi, promosi, pelayanan adinistrasi kantor)

PS = pengembangan sekolah (kompetensi kepala sekolah, kegiatan guru dan karyawan, pengembangan ICT, pengembangan SDM guru dan karyawan, pengembangan profesi pendidik 


\section{HASIL DAN PEMBAHASAN}

\section{Besarnya Biaya Satuan (Unit Cost) dengan ABC}

Biaya satuan (unit cost) merupakan biaya rata-rata per siswa yang dikeluarkan untuk memperoleh pendidikan dalam suatu kurun waktu tertentu. Unit cost ini dapat dijadikan sebagai standar biaya pendidikan per siswa yang dapat dibandingkan antar paket keahlian, tingkat, sekolah.

$\mathrm{ABC}$ merupakan suatu sistem kalkulasi biaya yang dalam mengukur pembebanan biayayanya didasarkan atas aktivitas. ABC adalah pembebanan biaya yang didesain untuk menyediakan informasi biaya sebagai dasar pengambilan keputusan baik strategis maupun keputusan lain yang mempengaruhi kapasitas (Noreen, Brewer \& Garrison, 2008: 235). ABC masih baru namun akurat untuk mementukan biaya (Blocher, Stout \& Cokins, 2011: 202). ABC dapat menghasilkan perbedaan evaluasi biaya dan keuntungan dari pada metode perhitungan biaya yang lebih sederhana (Cooper, R. \& Kaplan, R. S, 1988)

Tahap perhitungan yang digunakan yaitu identifikasi Aktivitas dan Atribut Aktivitas, pembebanan biaya ke Aktivitas, pengumpulan biaya dalam cost pool dan pembebanan biaya pada produk (Hansen \& Mowen, 2009: 176-185). Dalam penelitian ini produk adalah siswa karena siswa adalah pihak penikmat jasa di sekolah.

Hasil setiap tahan penerapan ABC sebagai berikut. Tahap pertama implementasi ABC adalah identifikasi aktivitas dan atribut aktivitas. Tahap ini perlu dilakukan untuk mempermudah peneliti dalam melakukan perhitungan menggunakan Metode ABC. Identifikasi aktivitas menunjukkan bahwa total biaya pendidikan di SMKN 2 Yogyakarta adalah Rp22.770.537.616,00. Berdasarkan identifikasi, 63,62\% biaya merupakan Aktivitas Primer dan 36,38\% merupakan Aktivitas Sekunder. Aktivitas Primer adalah aktivitas yang digunakan secara langsung oleh obyek biaya atau siswa. Aktivitas Sekunder adalah aktivitas yang digunakan oleh aktivitas lainnya, baik aktivitas primer maupun aktivitas sekunder lain (Hansen \& Mowen, 2009: 179).

Tahap kedua adalah pembebanan biaya yang terdiri dari dua tahap, yaitu 1) pembebanan biaya sumber daya ke aktivitas yang dihitung berdasarkan resource consumption cost driver dan 2) pembebanan Aktivitas Sekunder ke Aktivitas Primer sesuai dengan konsumsi aktivitas. Di SMKN 2 Yogyakarta biaya sumber daya dibebankan pada enam aktivitas yang terdiri dari dua Aktivitas Primer dan empat Aktivitas Sekunder. Aktivitas Primer terdiri dari Aktivitas Belajar Mengajar dan Kesiswaan, sedangkan Aktivitas Sekunder terdiri dari Pengelolaan Sarana Prasarna, Manajemen Sekolah, Administrasi Sekolah, Pengembangan Sekolah, Pembiayaan Listrik, Air, Telepon, dan Pembiayaan Tenaga Kependidikan. Pada tahap pembebanan kedua, biaya Aktivitas Sekunder dibebankan ke Aktivitas Primer. Pembebanan dilakukan karena Aktivitas Belajar Mengajar dan Kesiswaan menggunakan output dari Aktivitas Pengelolaan Sarana Prasarna, Manajemen Sekolah, Administrasi Sekolah, Pengembangan Sekolah, Pembiayaan Listrik, Air, Telepon, dan Pembiayaan Tenaga Kependidikan.

Tahap ketiga adalah pengumpulan aktivitas. Pengumpulan aktivitas yang memiliki rasio konsumsi sama perlu dilakukan untuk menyederhanakan perhitungan biaya (Hansen \& Mowen, 2009; 186). Biaya dikelompokkan dalam suatu pusat biaya atau cost pool. Activity Cost Pool di SMKN 2 Yogyakarta ada tujuh, yaitu Activity Cost Pool pada Kegiatan Belajar Mengajar (kemudian akan disingkat dengan KBM) antar Paket Keahlian, Activity Cost Pool KBM antar Rombel, Activity Cost Pool KBM Seluruh Siswa, Activity Cost Pool KBM Kelas XII, Activity Cost Pool KBM berdasarkan Jam Pelajaran, Activity Cost Pool Kesiswaan Khusus Kelas X, Activity Cost Pool Kesiswaan Seluruh Siswa.

Berdasarkan Tabel 1, Aktivitas Belajar Mengajar terbagi ke dalam lima cost pool. Biaya yang masuk dalam Activity Cost Pool KBM antar Paket Keahlian adalah Penerimaan Peserta Didik Baru (PPDB), Sarana Penunjang KBM, dan Praktik Fisika Kimia. Biaya yang masuk ke dalam Activity 
Cost Pool KBM antar Rombel adalah Penyusunan Kriteria Kenaikan Kelas, Klinik Mata Pelajaran, Bimbingan Belajar, Pemantaun KBM, Ujian Tengah Semester, Ujian Akhir Semester, Ujian Kompetensi, serta Alat Pembelajaran dan Olahraga. Biaya yang masuk dalam Activity Cost Pool KBM Seluruh Siswa adalah Pameran Pendidikan, TPA, Outdoor Study, dan Pelayanan KMS. Biaya yang masuk dalam Activity Cost Pool KBM Kelas XII adalah Pendalaman Materi, Try Out, Ujian Sekolah, Ujian Nasional, Praktik Kerja Lapangan, Ujian Kompetensi Kejuruan, dan Tutorial UN. Biaya yang masuk dalam Activity Cost Pool KBM berdasarkan Jam Pelajaran adalah Penyusunan Prota (program tahunan) dan Prosem (program semester), Penyusunan Silabus dan RPP, Workshop Validasi RPP, Bedah SKL, dan Sinkronisasi Validasi Kurikulum.

Tabel 1. Aktivitas di SMKN 2 Yogyakarta

\begin{tabular}{lrc}
\hline \multicolumn{1}{c}{ Jenis Aktivitas } & $\begin{array}{r}\text { Jumlah Biaya Aktivitas } \\
(\mathrm{Rp})\end{array}$ & Keterangan \\
\hline Kunjungan Industri & 13.650 .000 & Primer \\
Activity Cost Pool KBM antar Paket Keahlian & 1.536 .335 .075 & Primer \\
Activity Cost Pool KBM antar Rombel & 1.151 .150 .700 & Primer \\
Activity Cost Pool KBM Seluruh Siswa & 495.745 .000 & Primer \\
Activity Cost Pool KBM Kelas XII & 530.500 .500 & Primer \\
Activity Cost Pool KBM berdasarkan Jam Pelajaran & 265.682 .000 & Primer \\
Activity Cost Pool Kesiswaan Khusus Kelas X & 5.750 .000 & Primer \\
Activity Cost Pool Kesiswaan Seluruh Siswa & 1.970 .911 .300 & Primer \\
Pengelolaan Sarana Prasarana & 1.810 .261 .500 & Sekunder \\
Manajemen Sekolah & 1.133 .748 .000 & Sekunder \\
Administrasi Sekolah & 2.400 .872 .450 & Sekunder \\
Pengembangan Sekolah & 2.077 .591 .950 & Sekunder \\
Pembiayaan Listrik, Air, dan Telepon & 277.220 .541 & Sekunder \\
Pembiayaan Tenaga Pendidik & 8.517 .598 .600 & Sekunder \\
Pembiayaan Tenaga Kependidikan & 583.520 .000 & Primer \\
\hline
\end{tabular}

Aktivitas Kesiswaan terbagi ke dalam dua cost pool. Biaya yang masuk dalam Activity Cost Pool Kesiswaan Khusus Kelas X adalah kegiatan Masa Orientasi Studi. Biaya yang masuk dalam Activity Cost Pool Kesiswaan Seluruh Siswa diantaranya yaitu Lomba, Minat Baca Siswa, Tujuh K, Porseni dan Por Kreativitas, Bimbingan Konseling, Pembinaan Imtaq, Ekstrakulikuler, Pertukaran Pelajar dan lain-lain.

Tahap keempat yaitu penentuan dan perhitungan cost driver. Tahap ini dilakukan untuk membebankan Biaya Aktivitas ke obyek biaya, yaitu siswa. Penentuan jumlah cost driver dalam Activity Based Costing sangat penting (Cooper, 1989; Babad and Balachandran, 1993; Schniederjans and Garvin, 1997). Karakteristik yang harus diperhatikan dalam penentuan cost driver yaitu concealment, relevance, applicability dan accountability (Sheng, 2009). Tidak ada standar dalam penentuan cost driver yang dapat diterapkan untuk semua jenis organisasi maupun lembaga (Toompu \& Põlajeva, 2014), sehingga penentuan cost driver (didasarkan pada asumsi yang dirumuskan berdasarkan identifikasi aktivitas.

Setelah cost driver ditentukan dan dihitung, kemudian Biaya Aktivitas dibebankan pada siswa.Pembebanan biaya ke siswa didasarkan pada konsumsi aktivitas masing-masing obyek biaya, sehingga perlu dihitung tarif masing-masing aktivitas agar dapat dibebankan. Tarif aktivitas dihitung berdasarkan biaya aktivitas dan cost driver quantity dari masing-masing jenis aktivitas. Rumus perhitungan tarif aktivitas yaitu:

$$
\text { Tarif Aktivitas }=\frac{\text { Jumlah Biaya Aktivitas }}{\text { Jumlah Cost Driver }}
$$


Tabel 2. Penentuan Cost Driver dan Tarif Aktivitas

\begin{tabular}{llr}
\hline \multicolumn{1}{c}{ Aktivitas } & \multicolumn{1}{c}{ Cost Driver } & \multicolumn{1}{c}{$\begin{array}{r}\text { Tarif Aktivitas } \\
\text { (Rp) }\end{array}$} \\
\hline Kunjungan Industri & Jumlah siswa kelas XII & $21.000,00$ \\
Activity Cost Pool KBM antar Paket Keahlian & Prorata paket keahlian & $170.703 .897,22$ \\
Activity Cost Pool KBM antar Rombel & Jumlah rombel & $50.050 .030,43$ \\
Activity Cost Pool KBM Seluruh Siswa & Jumlah siswa & $4.383 .921,98$ \\
Activity Cost Pool KBM Kelas XII & Jumlah siswa kelas XII & $816.154,62$ \\
Activity Cost Pool KBM berdasarkan Jam Pelajaran & Jumlah Jam Pelajaran & $58.775,62$ \\
Activity Cost Pool Kesiswaan Khusus Kelas X & Jumlah siswa kelas X & $7.920,11$ \\
Activity Cost Pool Kesiswaan Seluruh Siswa & Jumlah siswa & $1.468 .776,06$ \\
\hline
\end{tabular}

Pembebanan pada obyek biaya dihitung dengan mengalikan tarif aktivitas dengan besarnya activity consumption masing-masing obyek biaya. Penentuan besarnya activity consumption didasarkan pada wawanara kepada stakeholders yang mengetahui biaya pendidikan di SMKN 2 Yoyakarta, yaitu Bendahsara Sekolah dan Wakil Kepala Sekolah dari berbagai bidang. Contoh pembebanan pada Paket Keahlian Teknik Gambar Bangunan kelas X terdapat pada tabel 3.

Penentuan activity consumption (AC) didasarkan pada wawancara dan identifikasi biaya. Activity consumption untuk Aktivitas KBM antar Paket Keahlian adalah 1/3 atau sebesar 0,33 dari tarif yang telah dihitung karena pada setiap Paket Keahlian terdapat tiga tingkat sehingga tarif aktivitas dibagi tiga dengan alokasi sama bagi setiap tingkat. Activity consumption untuk Activity Cost Pool KBM antar Rombel adalah tiga. Hal tersebut disebabkan karena jumlah rombongan belajar siswa Paket Keahlian Teknik Gambar Bangunan Kelas X berjumlah tiga. Besarnya activity consumption untuk Activity Cost Pool KBM untuk Seluruh Siswa adalah 95 karena siswa paket keahlian Teknik Gambar Bangunan Kelas X berjumlah 95.

Tabel 3. Perhitungan Biaya Satuan Siswa Paket Keahlian Teknik Gambar Bangunan kelas X

\begin{tabular}{|c|c|c|c|c|}
\hline \multirow[b]{2}{*}{ No } & \multirow[b]{2}{*}{ Aktivitas } & \multirow[b]{2}{*}{$\begin{array}{l}\text { Tarif } \\
\text { (Rp) }\end{array}$} & \multicolumn{2}{|c|}{ Kelas X } \\
\hline & & & $A C$ & $\begin{array}{c}\text { Biaya } \\
\text { (Rp) }\end{array}$ \\
\hline & \multicolumn{4}{|l|}{ Aktivitas Belajar Mengajar } \\
\hline 1 & Kunjungan Industri & - & - & \\
\hline 2 & Activity Cost Pool KBM antar Paket Keahlian & $170.703 .897,22$ & 0,33 & $56.901 .299,07$ \\
\hline 3 & Activity Cost Pool KBM antar Rombel & $50.050 .030,43$ & 3 & $150.150 .091,30$ \\
\hline 4 & Activity Cost Pool KBM antar Seluruh Siswa & $4.383 .921,98$ & 95 & $416.472 .588,52$ \\
\hline 5 & Activity Cost Pool KBM antar Kelas XII & $816.154,62$ & & \\
\hline \multirow[t]{2}{*}{6} & Activity Cost Pool KBM berdasarkan Jam Pelajaran & $58.576,84$ & 5700 & $333.888 .013,33$ \\
\hline & Aktivitas Kesiswaan & & & \\
\hline 1 & Activity Cost Pool Kesiswaan Khusus Kelas X & $7.920,11$ & 95 & $752.410,47$ \\
\hline 2 & Activity Cost Pool Kesiswaan Seluruh Siswa & $1.468 .776,06$ & 270 & $396.569 .537,18$ \\
\hline \multicolumn{2}{|r|}{ Jumlah Biaya Keseluruhan } & & & $1.354 .733 .939,88$ \\
\hline \multicolumn{2}{|c|}{ Jumlah Siswa Per Tingkat } & & & 95,00 \\
\hline \multicolumn{2}{|c|}{ Biaya Satuan (Unit Cost) Siswa Per Tahun } & & & $14.260 .357,26$ \\
\hline \multicolumn{2}{|c|}{ Biaya Satuan (Unit Cost) Siswa Per Bulan } & & & $1.188 .363,11$ \\
\hline
\end{tabular}

Tabel 3 digunakan untuk menghitung biaya satuan pada setiap Paket Kealian dan Tingkat (kelas) di SMKN 2 Yogyakarta, sehingga diperoleh hasil perhitungan unit cost yang disajikan pada Tabel 4. 
Jurnal Ekonomi \& Pendidikan, 15(1), 2018

Tabel 4. Biaya Satuan berdasarkan ABC di SMKN 2 Yogyakarta

\begin{tabular}{lccc}
\hline \multirow{2}{*}{\multicolumn{1}{c}{ Paket Keahlian }} & \multicolumn{3}{c}{$\begin{array}{c}\text { Biaya Satuan } \\
\text { (Rp) }\end{array}$} \\
\cline { 2 - 4 } & Kelas X & Kelas XI & Kelas XII \\
\hline Teknik Gambar Bangunan & $1.188 .363,11$ & $1.184 .611,78$ & $1.384 .114,84$ \\
Teknik Konstruksi Batu \& Beton & $1.270 .933,79$ & $1.424 .116,30$ & $1.423 .997,15$ \\
Teknik Geomatika & $1.286 .233,54$ & $1.367 .978,82$ & $1.371 .304,48$ \\
Teknik Audio Video & $1.208 .318,37$ & $1.266 .466,57$ & $1.334 .479,45$ \\
Teknik Komputer \& Jaringan & $1.221 .705,65$ & $1.250 .966,67$ & $1.277 .465,19$ \\
Multimedia & $1.190 .322,83$ & $1.177 .885,47$ & $1.300 .987,08$ \\
Teknik Instalasi Tenaga Listrik & $1.168 .512,97$ & $1.209 .685,69$ & $1.391 .362,27$ \\
Teknik Pemesinan & $1.177 .255,69$ & $1.233 .740,00$ & $1.309 .304,31$ \\
Teknik Kendaraan Ringan & $1.178 .495,70$ & $1.243 .797,20$ & $1.352 .480,01$ \\
\hline
\end{tabular}

Berdasarkan perhitungan menggunakan model ABC, persentase biaya aktivitas di SMKN 2 Yogyakarta terdapat pada gambar 2.

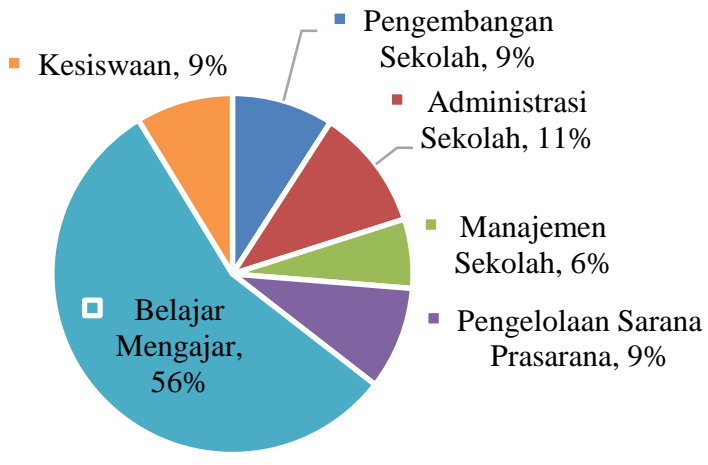

Gambar 2. Persentase Biaya Aktivitas SMKN 2 Yogyakarta

\section{Besarnya Biaya Satuan dengan Metode Tradisional}

Metode Tradisional digunakan oleh perusahaan manufaktur selama abad 20 untuk menentukan alokasi biaya overhead (Dwommor: 2012). Traditional Costing mengasumsikan bahwa biaya dapat diidentifikasi menjadi Biaya Langsung dan Biaya Tidak Langsung (Mowen \& Hansen, 2006: 45). Biaya Langsung adalah biaya yang dapat ditelusuri obyek biayanya. Biaya Tidak Langsung adalah biaya yang tidak dapat ditelusuri siapa obyeknya. Biaya Langsung dibebankan secara langsung pada obyek biaya sesuai konsumsi masing-masing, sedangkan Biaya Tidak Langsung (biaya overhead) dibebankan secara merata pada setiap obyek biaya, sehingga perhitungan tarif Biaya Tidak Langsung menggunakan satu dasar tunggal yaitu jumlah seluruh siswa SMKN 2 Yogyakarta. Rumus perhitungan Tarif Biaya Tidak Langsung adalah sebagai berikut:

$$
\text { Tarif Biaya Tidak Langsung }=\frac{\text { Jumlah Biaya Tidak Langsung }}{\text { Jumlah Seluruh Siswa }}
$$


Setelah menentukan tarif Biaya Langsung dan Biaya Tidak Langsung, biaya dibebankan pada obyek biaya berdasarkan jumlah siswa pada setiap Paket Keahlian dan Tingkat. Perhitungan Biaya Satuan berdasarkan Metode Tradisional dapat dilihat pada Tabel 5.

Tabel 5. Biaya Satuan Berdasarkan Metode Tradisional di SMKN 2 Yogyakarat

\begin{tabular}{lccc}
\hline \multirow{2}{*}{\multicolumn{1}{c}{ Paket Keahlian }} & \multicolumn{3}{c}{$\begin{array}{c}\text { Biaya Satuan } \\
(\text { Rp) }\end{array}$} \\
\cline { 2 - 4 } & Kelas X & Kelas XI & Kelas XII \\
\hline Teknik Gambar Bangunan & $1.112 .723,87$ & $1.116 .101,25$ & $1.253 .771,02$ \\
Teknik Konstruksi Batu \& Beton & $1.202 .152,70$ & $1.295 .171,62$ & $1.323 .404,68$ \\
Teknik Geomatika & $1.212 .138,27$ & $1.264 .660,35$ & $1.297 .541,23$ \\
Teknik Audio Video & $1.135 .551,64$ & $1.171 .894,00$ & $1.241 .656,88$ \\
Teknik Komputer \& Jaringan & $1.144 .289,01$ & $1.165 .359,28$ & $1.212 .979,81$ \\
Multimedia & $1.146 .369,99$ & $1.145 .291,36$ & $1.245 .718,81$ \\
Teknik Instalasi Tenaga Listrik & $1.094 .788,77$ & $1.120 .877,66$ & $1.248 .240,92$ \\
Teknik Pemesinan & $1.100 .494,80$ & $1.134 .452,99$ & $1.248 .240,92$ \\
Teknik Kendaraan Ringan & $1.099 .326,07$ & $1.137 .689,95$ & $1.228 .040,84$ \\
\hline
\end{tabular}

Perbandingan Hasil Perhitungan Unit Cost dengan Metode Tradisional dan Activity Based Costing Perhitungan berdasarkan kedua metode dibandingkan, hasil perhitungan menggunakan metode tradisional menunjukkan jumlah yang lebih sedikit daripada perhitungan menggunakan metode ABC. Hal ini menunjukkan bahwa sebenarnya konsumsi biaya overhead dari setiap obyek biaya berbeda-beda. Apabila dihitung dengan menggunakan ABC, konsumsi aktivitas sekunder pada setiap obyek biaya lebih besar dari konsumsi biaya yang dihitung menggunakan satu penggerak tunggal (Metode Tradisional). Biaya tertinggi adalah Biaya untuk Paket Keahlian Teknik Konstruksi Batu \& Beton Kelas XI. Berdasarkan informasi yang dihasilkan menggunakan perhitungan Metode $\mathrm{ABC}$, biaya pada Paket keahlian ini paling tinggi karena obyek biaya ini mengonsumsi biaya dengan rasio yang lebih tinggi dibandingkan paket keahlian dan tingkat lainnya.

Akyol, Tuncal, dan Bayhan (2007), menyatakan bahwa ABC dapat menghubungkan antara biaya produk dengan informasi produk. Artinya, dengan menerapkan ABC di sekolah maka dapat diketahui bagaimana kegiatan masing-masing siswa di setiap kelas dan paket keahlian, waktu yang dibutuhkan, dan dana yang terserap untuk setiap aktivitas pada paket keahlian dan tingkat yang berbeda.

Tabel 6 menyajikan perbandingan antara Biaya Satuan yang dihitung berdasarkan model ABC dengan jumlah pembiayan untuk setiap siswa. Jumlah pembiayaan diperoleh dari jumlah iuran kegiatan siswa, iuran rutin dewan sekolah, BOS, BOSDA, Dana APBN, Dana APBD Provinsi DIY, dan Dana APBD Kota Yogyakarta.

Dari Tabel 6, diketahui bahwa hasil perhitungan menggunakan metode Tradisional pada kelas $\mathrm{X}$ lebih besar daripada perhitungan menggunakan ABC. Namun pada kelas XI dan XII hasil perhitungan menggunakan metode Tradisional pada kelas X lebih kecil daripada perhitungan menggunakan $\mathrm{ABC}$. Hal ini menunjukkan bahwa siswa kelas $\mathrm{X}$ mensubsidi pelaksanaan kegiatan siswa kelas XI dan XII karena jumlah dana yang dialokasikan untuk siswa kelas X lebih tinggi daripada kelas XI dan XII. Subsidi silang ini dilakukan agar seluruh kegiatan sekolah dapat terlaksana sesuai dengan RKAS.

Berdasarkan hasil tersebut diketahui bahwa sebenarnya biaya kegiatan yang dikeluarkan untuk siswa kelas XI dan XII lebih besar, namun pihak sekolah menarik biaya yang lebih sedikit 
dibandingkan siswa kelas X. Sehingga dapat diketahui bahwa dana dari masyarakat, sponsor, dan pemerintah tidak hanya dikhususkan pada tingkat atau paket keahlian tertentu saja, namun dana tersebut dikumpulkan menjadi satu kemudian dialokasikan sesuai kebutuhan masing-masing tingkat dan paket keahlian.

Tabel 6. Perbandingan Hasil Perhitungan Biaya Satuan berdasarkan Model ABC dan Jumlah Pembiayaan untuk setiap siswa di SMKN 2 Yogyakarta

\begin{tabular}{llccr}
\hline \multirow{2}{*}{ Paket Keahlian } & \multicolumn{2}{c}{ Biaya per Siswa } & \\
\cline { 2 - 3 } & & $\begin{array}{c}\text { Metode Tradisional } \\
(\text { Rp) }\end{array}$ & $\begin{array}{c}\text { Metode ABC } \\
\text { (Rp) }\end{array}$ & Selisih (Rp) \\
\hline X & Teknik Gambar Bangunan & $1.305 .572,61$ & $1.188 .363,11$ & $117.209,50$ \\
& Teknik Konstruksi Batu \& Beton & $1.305 .572,61$ & $1.270 .933,79$ & $34.638,82$ \\
Teknik Geomatika & $1.305 .572,61$ & $1.286 .233,54$ & $19.339,07$ \\
Teknik Audio Video & $1.305 .572,61$ & $1.208 .318,37$ & $97.254,24$ \\
Teknik Komputer \& Jaringan & $1.305 .572,61$ & $1.221 .705,65$ & $83.866,96$ \\
Multimedia & $1.305 .572,61$ & $1.190 .322,83$ & $115.249,78$ \\
Teknik Instalasi Tenaga Listrik & $1.305 .572,61$ & $1.168 .512,97$ & $137.059,64$ \\
Teknik Pemesinan & $1.305 .572,61$ & $1.177 .255,69$ & $128.316,92$ \\
Teknik Kendaraan Ringan & $1.305 .572,61$ & $1.178 .495,70$ & $127.076,91$ \\
\hline XI & Teknik Gambar Bangunan & $905.572,61$ & $1.184 .611,78$ & $(279.039,17)$ \\
Teknik Konstruksi Batu \& Beton & $905.572,61$ & $1.424 .116,30$ & $(518.543,69)$ \\
Teknik Geomatika & $905.572,61$ & $1.367 .978,82$ & $(462.406,21)$ \\
Teknik Audio Video & $905.572,61$ & $1.266 .466,57$ & $(360.893,96)$ \\
Teknik Komputer \& Jaringan & $905.572,61$ & $1.250 .966,67$ & $(345.394,06)$ \\
Multimedia & $905.572,61$ & $1.177 .885,47$ & $(272.312,86)$ \\
Teknik Instalasi Tenaga Listrik & $905.572,61$ & $1.209 .685,69$ & $(304.113,08)$ \\
Teknik Pemesinan & $905.572,61$ & $1.233 .740,00$ & $(328.167,39)$ \\
Teknik Kendaraan Ringan & $905.572,61$ & $1.243 .797,20$ & $(338.224,59)$ \\
\hline XII & Teknik Gambar Bangunan & $1.013 .905,94$ & $1.384 .114,84$ & $(370.208,90)$ \\
Teknik Konstruksi Batu \& Beton & $1.013 .905,94$ & $1.423 .997,15$ & $(410.091,21)$ \\
Teknik Geomatika & $1.013 .905,94$ & $1.371 .304,48$ & $(357.398,54)$ \\
Teknik Audio Video & $1.013 .905,94$ & $1.334 .479,45$ & $(320.573,51)$ \\
Teknik Komputer \& Jaringan & $1.013 .905,94$ & $1.277 .465,19$ & $(263.559,25)$ \\
Multimedia & $1.013 .905,94$ & $1.300 .987,08$ & $(287.081,14)$ \\
Teknik Instalasi Tenaga Listrik & $1.013 .905,94$ & $1.391 .362,27$ & $(377.456,33)$ \\
Teknik Pemesinan & $1.013 .905,94$ & $1.309 .304,31$ & $(295.398,37)$ \\
Teknik Kendaraan Ringan & $1.013 .905,94$ & $1.352 .480,01$ & $(338.574,07)$ \\
\hline
\end{tabular}

\section{SIMPULAN}

Dari 6 aktivitas utama yang diidentifikasi di SMKN 2 Yogyakarta, biaya aktivitas belajar mengajar memperoleh porsi paling besar yaitu $55,77 \%$, paling rendah adalah biaya kegiatan manajemen sekolah sebesar 6,20\%. Sementara biaya aktivitas lainnya sekitar 9\%. Hal ini menunjukkan bahwa kegiatan sekolah masih on the right track yakni mengutamakan pada kegiatan belajar mengajar. Sementara itu, perhatian pada aktivitas manajemen sekolah paling rendah. Aktivitas pengembangan sekolah meski bukan yang paling rendah tetapi masih relatih rendah, mengingat aktivitas pengembangan sekolah merupakan komponen penting dalam usaha peningkatan kualitas pendidikan di sekolah. 
Unit cost per siswa dihitung dengan $\mathrm{ABC}$ dilihat antar Paket Keahlian berbeda-beda. Umumnya, faktor penentunya disebabkan karena aktivitas, besar kecilnya dana yang masuk dan jumlah siswa yang ada di masing-masing paket keahlian. Besarnya unit cost per siswa per paket keahlian berkisar dari $\mathrm{Rp}$ 1.168.513 sampai $\mathrm{Rp}$ 1.424.116.

Hasil perbandingan perhitungan menggunakan kedua metode (tradisional dan ABC) dapat dikategorikan menjadi dua, yaitu overcosted dan undercosted (Horngren, Datar, \& Foster, 2008: 161). Overcosted by Traditional Costing adalah suatu keadaan dimana hasil perhitungan menggunakan Metode Tradisional lebih tinggi daripada hasil perhitungan menggunakan metode ABC. Undercosted by Traditional Costing artinya hasil perhitungan menggunakan Metode Tradisional lebih rendah daripada hasil perhitungan menggunakan Metode ABC. Overcosted menunjukkan bahwa sebenarnya obyek biaya tersebut mengonsumsi biaya yang rendah, namun apabila dihitung menggunakan Metode Tradisional obyek biaya tersebut menanggung biaya yang tidak dikonsumsi oleh obyek biaya terkait. Biaya yang masuk dalam kategori overcosted adalah pada seluruh paket keahlian di kelas X. Undercosted menunjukkan bahwa sebenarnya obyek biaya tersebut mengonsumsi biaya yang tinggi, namun apabila dihitung menggunakan Metode Tradisional sebagian biaya yang dikonsumsi obyek biaya tersebut ditanggung oleh obyek biaya yang lain. Biaya yang masuk kategori undercosted adalah pada seluruh paket keahlian di kelas XI dan XII. Dengan penghitungan unit cost menggunakan model $\mathrm{ABC}$, bisa ditemukan alokasi biaya untuk kegiatan-kegiatan tertentu perlu di pertimbangkan dan dilakukan penelusuran lebih lanjut, mana kegiatan yang perlu dikurangi dan mana kegiatan yang perlu ditambah.

Berdasarkan temuan hasil penelitian, peneliti dapat memberikan saran sebagai berikut: 1) Temuan unit cost dengan model ABC seharusnya membawa implikasi tarif biaya yang dikenakan pada siswa di setiap Paket Keahlian berbeda-beda. Sekolah seharusnya menetapkan tarif biaya yang lebih rendah pada siswa di suatu paket keahlian yang mengkonsumsi biaya lebih rendah. Sebaliknya siswa di suatu paket keahlian yang mengkonsumsi biaya lebih tinggi dikenakan tarif biaya yang lebih tinggi pula, sehingga asas keadilan dapat diciptakan. 2) Kepala sekolah mulai mempersiapkan pengelolaan keuangan yang kondusif untuk bisa diterapkannya penghitungan unit cost dengan $A B C$. Penerapan model ABC di sekolah sangat perlu karena hasil perhitungan menggunakan model ABC dapat digunakan untuk membantu sekolah dalam proses pengambilan keputusan dan dijadikan sebagai salah satu dasar pelaksanaan efisiensi biaya. 3) Sekolah harus memiliki informasi biaya yang lengkap agar dapat digunakan sebagai pelengkap data untuk perhitungan unit cost menggunakan $\mathrm{ABC}$. Informasi tersebut akan berguna untuk membantu proses penentuan cost driver dan pembebanan biaya. Sebagai contoh, pembebanan aktivitas administrasi sekolah terpaksa dilakukan berdasarkan proporsi karena tidak diketahui cost driver nya. Sekolah seharusnya memiliki catatan pembebanan yang lebih lengkap agar perhitungan lebih akurat. 4) Sekolah sebaiknya menambah anggaran untuk melaksanakan kegiatan pengembangan sekolah, baik fisik maupun sumber daya manusia. Aktivitas pengembangan yang penting tetapi pengeluarannya relatif kecil antara lain, pengembangan kompetensi kepala sekolah, lesson study, publikasi ilmiah, simulasi digital, diklat pengembangan evaluasi WEB, serta pengembangan unit produksi dan jasa.

\section{DAFTAR PUSTAKA}

Abu-Tapanjeh, A. M. (2008). Activity-Based Costing Approach to Handle the Uncertainty Costing of Higher Educational Institutions: Perspective from an Academic College. Journal of King Abdul Aziz University, 2, 29-57. 
Akyol, D. E, Tuncen, G., \& Bayhan, G. M. (2007). A Comparative Analysis of Activity-Based Costing and Traditional Costing. International Scholarly and Scientific Research \& Innovation, Vol $1,3,136-139$.

Babad, Y. M. and Balachandran, B. V., 1993. Cost driver optimization in activity-based costing, The Accounting Review, July, 563-575.

Bustami, B. \& Nurlela. (2009). Akuntansi Biaya. Edisi Pertama. Jakarta. Penerbit: Mitra Wacana Media.

Blocher, E. J., Stout, D. E., \& Cokins, G. (2011). Manajemen Biaya. (Terjemahan David Wijaya). Jakarta: Salemba Empay. (Edisi asli diterbitkan tahun 2010 oleh McGraw-Hill 1221 Avenue of The Americas New York).

Carter, W.K \& Usry, M.F. (2006). Akuntansi Biaya Edisi 13 Jilid 1. (Terjemahan Krista). Jakarta: Salemba Empat. (Edisi asli diterbitkan tahun 2002 oleh Thomson Learning 5 Shenton Way Singapore).

Cooper, R. \& Kaplan, R. S. (1988). Measure the Cost Right: Make The Right Decision. Harvard Business Review, 66, 96-103.

Cooper, R. (1989). The Rise Of Activity-Based Costing Part Three: How Many Cost Drivers Do You Need, And How Do You Select Them? Journal of Cost Management, 2 (4), 34-46.

Dwommor, J. Y. (2012). The Practicability of Traditional Method of Overhead Allocation: A Case of Limited Liability Company in Developing Economy. Research Journal of Finance and Accounting, $6,1-12$.

Hansen, D. R. \& Mowen, M. M. (2009). Akuntansi Manajerial. (Terjemahan Deny Arnos Kwary). Jakarta: Penerbit Salemba Empat. (Edisi asli diterbitkan tahun 2007 oleh Cengage Learning Asia Pte Ltd. 5 Shenton Way Singapore).

Mowen, M. M. \& Hansen, D. R. (2006). Cost Management: Accounting and Control (5th ed). Mason: Thomson South Western Inc

Kementrian Pendidikan dan Kebudayaan. (2003). Undang-Undang RI Nomor 20, Tahun 2003, tentang Sistem Pendidikan Nasional.

Matin. (2014). Manajemen Pembiayaan Pendidikan. Jakarta: PT RajaGrafindo Persada.

Maelah, R., Amir, A. M., Ahmad, A., et al. (2011). Cost per Students Using ABC Aproach. International Proceedings of Economics Develompment and Research Vol 9, 7, 40-45.

Noreen, E. W., Brewer, P. C., \& Garrison, R. H. (2008). Managerial Accounting for Managers (2nd ed). New York: The McGraw-Hill Companies, Inc.

Raiborn, C. A \& Kinny, R. K. (2011). Akuntansi Biaya: Dasar dan Pengembangan. (Terjemahan Rahmat Hilman). Jakarta: Salemba Empat. (Edisi asli diterbitkan tahun 2009 oleh Cengage Learning Asia Pte Ltd 5 Shenton Way Singapore).

Schniederjans, M. J. and Garvin, T. (1997). Using the analytic hierarchy process and multiobjective programming for the selection of cost drivers in activity-based costing. European Journal of Operational Research, 100, 72-80.

Sheng, Y.M. (2009). Research on selection methods of cost driver. Journal of Modern Accounting and Auditing, 5(9), 52, 47-49.

Toompu, K. \& Põlajeva, T. (2014). Theoretical framework and an overview of the cost drivers that are applied in universities for allocating indirect costs. Procedia - Social and Behavioral Sciences, $110,1014-1022$. 